\title{
Investigation of Physical Activity Report Card Applications by Physical Education and Sport Teachers
}

\author{
Fatih Özgül ${ }^{1}$, Murat Kangalgil ${ }^{1}$, Oğuzhan Çalı ${ }^{2}$, Rahmi Yıldız ${ }^{2}$ \\ ${ }^{1}$ Cumhuriyet University Department of Physical Education and Sports, Sivas, Turkey \\ ${ }^{2}$ Ministry of National Education, Sivas, Turkey \\ Correspondence: Fatih Özgül, Cumhuriyet University Department of Physical Education and Sports, Sivas, Turkey.
}

Received: April 18, 2018

doi:10.11114/jets.v6i8.3217

Accepted: May28, 2018

Online Published: June 8, 2018

URL: https://doi.org/10.11114/jets.v6i8.3217

\begin{abstract}
The aim of this research is to examine the views of physical education and sports teachers who are trained and practice the physical activity report card applications according to some variables. The Physical Activity Report Card Applications Assessment Scale developed by Özgül et al. (2018) was applied in the study, by reaching 380 physical education and sports teachers (voluntary participation) determined according to the appropriate sampling method. The Cronbach Alpha score of the scale is .83. Scale; "Applicability, Impact, Difficulties, Forcing, Competence and Support" consists of 6 sub-dimensions. The point value that can be taken from the scale ranges from 38 to 190. In the evaluation of the obtained data; Mann Whitney U test and Kruskal Wallis Variance Analysis were applied because of the parametric test assumptions were not met and significance level was set to .05 . When the subscale and total scores of the teachers were compared according to the school type, statistically significant differences were found between them ( $\mathrm{p}<0.05$ ). The subscale and total scores obtained from the scale according to the age of seniority were compared and the difference was significant $(\mathrm{p}<0.05)$. Also, the difference between the mean scores of the "difficulty and support" subscales was found to be significant ( $\mathrm{p}<0.05$ ), while the difference between the other subscales was not significant ( $\mathrm{p}>$ 0.05). As a result of the research; It can be stated that the physical education and sports teachers participating in the Physical Activity Report Card measurement training do not see themselves enough for these measurements.
\end{abstract}

Keywords: application, physical education and sports teacher, physical activity report card, measurement

\section{Introduction}

Human needs action to be able to continue his life as a living physical entity in a higher quality. (9). Technological developments reduce the intensity of daily activities, and although it makes life easier, it increases the number of inactive individuals in the long run and affects health negatively. Those who are getting less involved in outdoor activities do not change the frequency and amount of nutrition while reducing the amount of energy they spend during the day. Inadequate physical activity results in adverse effects on the body as well as increased body weight (13). Excessive body weight and obesity, which are increasing day by day due to inadequate physical activity, are known to be health problems such as cardiovascular diseases, mental disorders, musculoskeletal injuries (16). Physical activity; increases the energy expenditure of the individual to prevent obesity and the control of energy balance and body weight that is one of the most important health problems faced by modern societies (17). Inadequate physical activity carries serious health risks not only for adults but also for children and young people. The most important factors to become chronic diseases are inactivity and malnutrition apart from genetic, environmental and biological factors. Many chronic diseases that we have become accustomed to seeing in advanced ages are now observed in childhood because of the adoption of a sedentary lifestyle. For this reason, there is a separate proposition to increase the movement in children from infancy and to reduce the number of days spent in motion during the day. In addition to childhood illnesses, regular physical activity and sport are among the basic strategies, especially for school children, to prevent many underlying diseases in childhood. Regular physical activities are known to contribute to cognitive development in children, thereby positively affecting school achievement and enabling them to acquire a more social and regular life habit (17). Although children are more active than adults, their activity levels decline as they move toward adolescence, and significant numbers of young people do not participate in recommended levels of physical activity (2). A number of studies that incorporated health-related physical education concepts and used physical activity as the primary outcome have been conducted in the USA (5-7). Physical Education teachers have a great responsibility, who are 
characterized by schools to help them settled in their physical activity habits, to develop a healthy lifestyle, and contribute to the development of basic knowledge of children's skills and attitudes about physical activity in this context. For this purpose, a physical activity project for health has been initiated in the Ministry of National Education and Ministry of Health. Under this project physical activity report card application from the year 2016, in general (public-private) secondary and high schools of Turkey in the academic year are held two times a year, in the first and second periods. In the application, physical parameters are assessed by measuring push-in, sit-up flexibility, body weight and height tests of the students (9). The Ministry of National Education has provided "tutorial training" to the heads of physical education teachers at the schools with training videos describing the movement for health and the prejudice of physical activity. These activities, which began in Turkey has brought with it the need for scientific research. Due to these reasons, studies investigating the state of physical activity are important in terms of emphasizing the importance of physical activity in the Ministry of National Education or Ministry of Health institutions, determining the current situation for a healthy, productive and quality future, presenting problems and proposing solution proposals. From this point of view, the aim of this study is to examine the opinions of physical education and sports teachers regarding the practices of physical activity report card applications, which are trained in physical activity report card application, according to some variables.

\section{Method}

\subsection{Research Design}

Appropriate sampling method was used in the selection of the sample. Appropriate sampling; Due to the limitations in terms of time, money and labor, sampling is to be selected from easily accessible and practicable units (1). The Assessment Scale of Physical Activity Report Card Applications was applied to a total of 380 physical education and sports teachers, 116 female and 264 male, determined according to the appropriate sampling method in the study.

\subsection{Data Collection Tools}

5 li likert type "Assessment Scale of Physical Activity Report Card Applications" developed by Özgül, Kangalgil, Çalı and Yildiz (2018) was used in the research. The scale consists of 24 items in a total and 3 items are scored inversely. The Cronbach Alpha $(\alpha)$ internal consistency coefficient of the scale was .83. Scale; "Applicability, Impact, Difficulties, Forcing, Competence and Support" consists of 6 sub-dimensions and Cronbach Alpha $(\alpha)$ internal consistency coefficients for sub-dimensions, respectively; 0.87 for the Applicability sub-dimension, 0.80 for the Impact sub-dimension, 0.60 for the Difficulties sub-dimension, 0.75 for the Forcing sub-dimension, 0.82 for the Competence sub-dimension, and 0.76 for the Support sub-dimension. The score that can be taken from the scale ranges from 38 to 190.

\subsubsection{Analysis of Data}

Kruskal Wallis Analysis of Variance and Mann Whitney U test were used because the parametric test assumptions were not fulfilled in evaluating the data obtained in the study, and the significance level was set to .05 .

\section{Results}

In this section, the data about the research are presented in the tables.

Table 1. Distribution of Teachers by Gender, Type of School, Seniority Year, Place of Residence and Educational Status

\begin{tabular}{llll}
\hline Variable & & f & \% \\
\hline \multirow{2}{*}{ Gender } & Male & 264 & 69,3 \\
& Female & 116 & 29,7 \\
\hline \multirow{2}{*}{ School Type } & Middle School & 210 & 55,2 \\
& High School & 170 & 44,8 \\
\hline \multirow{3}{*}{ Seniority Year } & 1-5 year & 78 & 20,5 \\
& 6-10 year & 91 & 23,9 \\
& 11-15 year & 112 & 29,4 \\
& 16-20 year & 53 & 13,9 \\
\multirow{3}{*}{ Place of Residence } & 21 year above & 46 & 12,1 \\
& City Center & 247 & 65 \\
& Town Center & 95 & 25 \\
\multirow{2}{*}{ Educational Status } & Village & 38 & 10 \\
\hline \multirow{2}{*}{ Graduation Department } & Undergraduate & 346 & 91,9 \\
& Master Degree & 34 & 8,9 \\
\hline Total & Physical Education and Sports Teaching & 366 & 96,3 \\
& Other Departments & 14 & 3,7 \\
\hline
\end{tabular}

A total of 380 teachers participating in the study consisted of $69.3 \%$ male and $29.7 \%$ female teachers according to the 
gender variable. According to the school type, 55.2\% of the teachers are working in secondary school and $44.8 \%$ are working in high school. According to the age of seniority, 20.5\% of teachers are 1-5 years, $23.9 \%$ is 6-10 years, $29.4 \%$ is $11-15$ years, $13.9 \%$ is $16-20$ years and \% 12,1 have 21 years and over the seniority year. According to the type of settlement, $65 \%$ of the teachers are in the province center, $25 \%$ are in the district center and $10 \%$ are working in the villages. According to the educational status variable, $91.9 \%$ of the teachers are undergraduate and $8.9 \%$ are master degree students. According to the graduated department variable; $96.3 \%$ are from physical education and sports teaching department and 3.7\% are from other departments (graduated from the Department of Coaching Education, Sports Management and Recreation Department).

Table 2. Comparison of teachers' total and subscale average scores by gender variable

\begin{tabular}{lllllllll}
\hline Sub-Scales & Gender & $\mathbf{N}$ & $\mathbf{X}$ & S.D. & Median & Min & Max & Result \\
\hline Applicability & Male & 264 & 28.51 & 9.10 & 29,00 & 10.00 & 50.00 & \multirow{2}{*}{$\mathrm{P}=0,893$} \\
& Female & 116 & 28.06 & 9.80 & 30,50 & 11.00 & 45.00 & \\
\hline Impact & Male & 264 & 27.58 & 7.21 & 28,00 & 13.00 & 41.00 & \multirow{2}{*}{$\mathrm{P}=0,799$} \\
& Female & 116 & 27.89 & 6.57 & 27,50 & 13.00 & 41.00 & \\
\hline Difficulties & Male & 264 & 21.01 & 3.89 & 21,00 & 10.00 & 30.00 & \multirow{2}{*}{$\mathrm{P}=0,833$} \\
& Female & 116 & 20.67 & 4.42 & 21,00 & 6.00 & 27.00 & \\
\hline Forcing & Male & 264 & 10.39 & 3.39 & 11,00 & 3.00 & 15.00 & \multirow{2}{*}{$\mathrm{P}=0,481$} \\
& Female & 116 & 10.65 & 3.33 & 11,00 & 4.00 & 15.00 & \\
\hline Competence & Male & 264 & 14.51 & 4.13 & 16,00 & 4.00 & 20.00 & \multirow{2}{*}{$\mathrm{P}=0,669$} \\
& Female & 116 & 14.63 & 4.23 & 15,00 & 6.00 & 20.00 & \\
\hline \multirow{2}{*}{ Support } & Male & 264 & 13.22 & 2.88 & 14,00 & 4.00 & 19.00 & \multirow{2}{*}{$\mathrm{P}=0,430$} \\
& Female & 116 & 13.08 & 2.89 & 13,50 & 6.00 & 19.00 & \\
\hline Total & Male & 264 & 149.27 & 20.83 & 150,00 & 79.00 & 214.00 & \multirow{2}{*}{$\mathrm{P}=0,418$} \\
& Female & 116 & 147.08 & 21.22 & 149,00 & 94.00 & 186.00 & \\
\hline
\end{tabular}

According to gender variable, there were no significant differences between teachers in terms of subscale and total scores of the scale $(p>0.05)$.

Table 3. Comparison of teacher's total and subscale average scores by school type variable

\begin{tabular}{|c|c|c|c|c|c|c|c|c|}
\hline Sub-Scales & School Type & $\mathbf{N}$ & $\mathbf{X}$ & S.D. & Median & Min & Max & Result \\
\hline \multirow[t]{2}{*}{ Applicability } & Middle School & 210 & 29.24 & 8.29 & 30,00 & 10.00 & 45.00 & \multirow{2}{*}{$\mathrm{P}=0,087$} \\
\hline & High School & 170 & 27.31 & 10.35 & 30,00 & 11.00 & 50.00 & \\
\hline \multirow[t]{2}{*}{ Impact } & Middle School & 210 & 27.97 & 7.32 & 28,00 & 13.00 & 41.00 & \multirow{2}{*}{$\mathrm{P}=0,288$} \\
\hline & High School & 170 & 27.31 & 6.61 & 27,00 & 13.00 & 41.00 & \\
\hline \multirow[t]{2}{*}{ Difficulties } & Middle School & 210 & 20.97 & 4.04 & 21,00 & 7.00 & 27.00 & \multirow{2}{*}{$\mathrm{P}=0,710$} \\
\hline & High School & 170 & 20.82 & 4.09 & 21,00 & 6.00 & 30.00 & \\
\hline \multirow[t]{2}{*}{ Forcing } & Middle School & 210 & 9.88 & 3.42 & 10,00 & 3.00 & 15.00 & \multirow{2}{*}{$\mathrm{P}=0,001$ * } \\
\hline & High School & 170 & 11.21 & 3.16 & 12,00 & 3.00 & 15.00 & \\
\hline \multirow{2}{*}{ Competence } & Middle School & 210 & 15.25 & 3.65 & 16,00 & 4.00 & 20.00 & \multirow{2}{*}{$\mathrm{P}=0,005^{*}$} \\
\hline & High School & 170 & 13.68 & 4.56 & 15,00 & 4.00 & 20.00 & \\
\hline \multirow{2}{*}{ Support } & Middle School & 210 & 12.98 & 3.12 & 13,00 & 4.00 & 19.00 & \multirow{2}{*}{$\mathrm{P}=0,272^{*}$} \\
\hline & High School & 170 & 13.42 & 2.54 & 14,00 & 8.00 & 19.00 & \\
\hline \multirow{2}{*}{ Total } & Middle School & 210 & 150.23 & 18.79 & 151,50 & 94.00 & 188.00 & \multirow{2}{*}{$\mathrm{P}=0,032 *$} \\
\hline & High School & 170 & 146.58 & 23.23 & 147,00 & 79.00 & 214.00 & \\
\hline
\end{tabular}

\section{*p $<0.05$ significant}

When the subscale and total scores of the teachers are compared according to the school type, statistically significant differences were found between them $(p<0.05)$. While the difference between the subscale scores of "Forcing, Competence, Support" were significant $(\mathrm{p}<0.05)$, the difference between the other subscale scores were not significant $(\mathrm{p}>0.05)$. 
Table 4. Comparison of teachers' total and subscale average scores according to seniority year variable

\begin{tabular}{|c|c|c|c|c|c|c|c|c|}
\hline Sub-Scales & Seniority Year & $\mathbf{N}$ & $\mathbf{X}$ & S.D. & Median & Min & Max & Result \\
\hline \multirow{5}{*}{ Applicability } & $1-5$ year & 78 & 28.87 & 9.40 & 30,00 & 10.00 & 50.00 & \multirow{5}{*}{$\begin{array}{l}\mathrm{KW}=12,87 \\
\mathrm{P}=0,012 *\end{array}$} \\
\hline & $6-10$ year & 91 & 29.45 & 8.18 & 30,00 & 13.00 & 50.00 & \\
\hline & $11-15$ year & 112 & 25.84 & 10.12 & 27,50 & 11.00 & 40.00 & \\
\hline & $16-20$ year & 53 & 28.20 & 9.74 & 28,00 & 12.00 & 45.00 & \\
\hline & 21 year + & 46 & 31.80 & 7.20 & 32,00 & 14.00 & 40.00 & \\
\hline \multirow{5}{*}{ Impact } & $1-5$ year & 78 & 27.78 & 7.57 & 28,00 & 13.00 & 41.00 & \multirow{5}{*}{$\begin{array}{l}K W=2,73 \\
P=0,603\end{array}$} \\
\hline & $6-10$ year & 91 & 28.19 & 7.45 & 28,00 & 13.00 & 41.00 & \\
\hline & $11-15$ year & 112 & 26.98 & 5.87 & 28,00 & 13.00 & 40.00 & \\
\hline & $16-20$ year & 53 & 27.41 & 5.56 & 27,00 & 15.00 & 37.00 & \\
\hline & 21 year + & 46 & 28.50 & 9.07 & 28,00 & 13.00 & 41.00 & \\
\hline \multirow{5}{*}{ Difficulties } & $1-5$ year & 78 & 20.93 & 4.39 & 22,00 & 6.00 & 27.00 & \multirow{5}{*}{$\begin{array}{l}\mathrm{KW}=6,08 \\
\mathrm{P}=0,193\end{array}$} \\
\hline & $6-10$ year & 91 & 21.32 & 3.94 & 21,00 & 13.00 & 30.00 & \\
\hline & $11-15$ year & 112 & 21.40 & 3.51 & 22,00 & 14.00 & 26.00 & \\
\hline & $16-20$ year & 53 & 20.26 & 3.74 & 21,00 & 13.00 & 26.00 & \\
\hline & 21 year + & 46 & 19.56 & 4.95 & 20,00 & 7.00 & 26.00 & \\
\hline \multirow{5}{*}{ Forcing } & $1-5$ year & 78 & 9.46 & 3.54 & 10,00 & 3.00 & 15.00 & \multirow{5}{*}{$\begin{array}{l}\mathrm{KW}=13,97 \\
\mathrm{P}=0,007^{*}\end{array}$} \\
\hline & $6-10$ year & 91 & 10.06 & 3.57 & 11,00 & 3.00 & 15.00 & \\
\hline & $11-15$ year & 112 & 10.85 & 3.07 & 12,00 & 3.00 & 15.00 & \\
\hline & $16-20$ year & 53 & 11.35 & 3.00 & 12,00 & 4.00 & 15.00 & \\
\hline & 21 year + & 46 & 11.06 & 3.34 & 12,00 & 4.00 & 15.00 & \\
\hline \multirow{5}{*}{ Competence } & $1-5$ year & 78 & 15.16 & 4.06 & 16,00 & 4.00 & 20.00 & \multirow{5}{*}{$\begin{array}{l}\mathrm{KW}=21,16 \\
\mathrm{P}=0,007^{*}\end{array}$} \\
\hline & $6-10$ year & 91 & 15.29 & 4.23 & 16,00 & 6.00 & 20.00 & \\
\hline & $11-15$ year & 112 & 13.05 & 4.37 & 14,00 & 4.00 & 20.00 & \\
\hline & $16-20$ year & 53 & 14.75 & 3.63 & 15,00 & 8.00 & 20.00 & \\
\hline & 21 year + & 46 & 15.45 & 3.27 & 15,50 & 8.00 & 20.00 & \\
\hline \multirow{5}{*}{ Support } & $1-5$ year & 78 & 12.26 & 2.29 & 12,00 & 6.00 & 16.00 & \multirow{5}{*}{$\begin{array}{l}\mathrm{KW}=36,13 \\
\mathrm{P}=0,001^{*}\end{array}$} \\
\hline & $6-10$ year & 91 & 12.85 & 2.53 & 13,00 & 8.00 & 18.00 & \\
\hline & $11-15$ year & 112 & 14.21 & 2.99 & 15,00 & 4.00 & 19.00 & \\
\hline & $16-20$ year & 53 & 13.35 & 3.29 & 14,00 & 4.00 & 19.00 & \\
\hline & 21 year + & 46 & 12.65 & 2.99 & 13,00 & 8.00 & 19.00 & \\
\hline \multirow{5}{*}{ Total } & $1-5$ year & 78 & 148.05 & 22.89 & 149,00 & 79.00 & 202.00 & \multirow{5}{*}{$\begin{array}{l}\mathrm{KW}=9,13 \\
\mathrm{P}=0,052\end{array}$} \\
\hline & $6-10$ year & 91 & 151.32 & 22.61 & 154,00 & 94.00 & 214.00 & \\
\hline & $11-15$ year & 112 & 143.85 & 19.59 & 143,00 & 101.00 & 179.00 & \\
\hline & $16-20$ year & 53 & 150.73 & 16.98 & 151,00 & 117.00 & 184.00 & \\
\hline & 21 year + & 46 & 153.26 & 19.90 & 157,00 & 111.00 & 187.00 & \\
\hline
\end{tabular}

${ }^{*} \mathrm{p}<0.05$ significant

When the sub-scale and total scores obtained from the scale according to the variable of seniority year are compared; While there was significant difference between the sub-dimensions of "Applicability, Forcing, Competence and Support" ( $p<0.05$ ), the difference between the other sub-dimensions and total scores was not significant ( $p>0.05)$. When the scores were compared with each other, the difference was significant in the "Applicability" sub-dimension, between 6-10 years and 11-15 years, between 11-15 years and 21 years $(p<0.05)$, while the difference between the other years was not significant ( $>>0.05)$. The difference between 1-5 years and 11-15 years, between 1-5 years and 16-20 years was significant $(\mathrm{p}<0.05)$, while the difference between the other years was not significant $(\mathrm{p}>0.05)$ at "Forcing" sub-scale scores. While the difference in the "Qualification" sub-scale between 1-5 years and 11-15 years, between 6-10 years and 11-15 years, between 11-15 years and above 21 years were significant $(p<0.05)$, the difference between the other years was not significant ( $>0.05)$. While the differences in the "Support" sub-dimension, between 1-5 years and 11-15 years, between 6-10 years and 11-15 years, between 11-15 years and 21 years were significant $(\mathrm{p}$ $<0.05)$, between the other years was not significant ( $p>0.05)$. Compared to the year of the seniority, the difference was not significant when compared to the total points $(\mathrm{p}>0.05)$. 
Table 5. Comparison of teachers' total and subscale averages by settlement region variable

\begin{tabular}{|c|c|c|c|c|c|c|c|c|}
\hline Sub-Scales & Settlement Region & $\mathbf{N}$ & $\mathbf{X}$ & S.D. & Median & Min & Max & Result \\
\hline \multirow{3}{*}{ Applicability } & City & 247 & 28.78 & 9.85 & 31,00 & 11.00 & 50.00 & \multirow{3}{*}{$\begin{array}{l}\mathrm{KW}=3,75 \\
\mathrm{P}=0,153\end{array}$} \\
\hline & Town & 95 & 27.55 & 8.48 & 28,00 & 10.00 & 50.00 & \\
\hline & Village & 38 & 27.78 & 7.53 & 28,00 & 11.00 & 40.00 & \\
\hline \multirow{3}{*}{ Impact } & City & 247 & 27.97 & 6.56 & 28,00 & 13.00 & 41.00 & \multirow{3}{*}{$\begin{array}{l}\mathrm{KW}=2,07 \\
\mathrm{P}=0,354\end{array}$} \\
\hline & Town & 95 & 26.61 & 8.12 & 27,00 & 13.00 & 41.00 & \\
\hline & Village & 38 & 28.47 & 6.80 & 30,00 & 16.00 & 39.00 & \\
\hline \multirow{3}{*}{ Difficulties } & City & 247 & 20.40 & 4.44 & 21,00 & 6.00 & 27.00 & \multirow{3}{*}{$\begin{array}{l}\mathrm{KW}=9,57 \\
\mathrm{P}=0,008^{*}\end{array}$} \\
\hline & Town & 95 & 22.09 & 2.83 & 22,00 & 15.00 & 27.00 & \\
\hline & Village & 38 & 21.21 & 3.44 & 20,00 & 16.00 & 30.00 & \\
\hline \multirow{3}{*}{ Forcing } & City & 247 & 11.33 & 3.03 & 12,00 & 3.00 & 15.00 & \multirow{3}{*}{$\begin{array}{l}\mathrm{KW}=48,58 \\
\mathrm{P}=0,001^{*}\end{array}$} \\
\hline & Town & 95 & 9.29 & 3.39 & 9,00 & 3.00 & 15.00 & \\
\hline & Village & 38 & 7.84 & 3.19 & 8,00 & 3.00 & 13.00 & \\
\hline \multirow{3}{*}{ Competence } & City & 247 & 14.12 & 4.12 & 15,00 & 4.00 & 20.00 & \multirow{3}{*}{$\begin{array}{l}\mathrm{KW}=10,35 \\
\mathrm{P}=0,006^{*}\end{array}$} \\
\hline & Town & 95 & 15.43 & 4.52 & 16,00 & 4.00 & 20.00 & \\
\hline & Village & 38 & 15.10 & 2.93 & 16,00 & 8.00 & 20.00 & \\
\hline \multirow{3}{*}{ Support } & City & 247 & 13.59 & 2.84 & 14,00 & 4.00 & 19.00 & \multirow{3}{*}{$\begin{array}{l}\mathrm{KW}=27,24 \\
\mathrm{P}=0,001^{*}\end{array}$} \\
\hline & Town & 95 & 11.86 & 2.86 & 12,00 & 4.00 & 16.00 & \\
\hline & Village & 38 & 13.78 & 2.17 & 14,00 & 8.00 & 17.00 & \\
\hline \multirow{3}{*}{ Total } & City & 247 & 149.74 & 21.03 & 153,00 & 79.00 & 202.00 & \multirow{3}{*}{$\begin{array}{l}\mathrm{KW}=3,36 \\
\mathrm{P}=0,186\end{array}$} \\
\hline & Town & 95 & 146.25 & 22.68 & 149,00 & 94.00 & 214.00 & \\
\hline & Village & 38 & 147.10 & 14.86 & 147,00 & 124.00 & 177.00 & \\
\hline
\end{tabular}

${ }^{*} \mathrm{p}<0.05$ significant

While differences in the mean scores of the teachers were found to be significant $(\mathrm{p}<0.05)$ in the "difficulties, forcing, competence and support" sub-dimensions according to settlement type variance ( $p<0.05)$, the differences in the other sub-scale scores were not found to be significant ( $>>0.05)$. When the groups are compared with each other; while there was a significant difference between province and district in the "difficulty" sub-scale points $(\mathrm{p}<0.05)$, the difference between the other settlement regions was not significant $(p>0.05)$. When the "forcing" subscale scores are compared with each other; There were significant differences between province and district, between province and village and between district and village ( $\mathrm{p}<0.05)$. When the "Competence" subscale scores are compared with each other; while the difference between province and district was significant $(\mathrm{p}<0.05)$, the difference was not significant among the others ( $p>0.05)$. In the "Support" sub-scale points, the difference between the province and town is significant $(\mathrm{p}<0.05)$, while the difference between the other settlement regions are not significant $(\mathrm{p}<0.05)$.

Table 6. Comparison of teachers' total and subscale averages by educational status variable

\begin{tabular}{lllllllll}
\hline Sub-Scales & Educational Status & $\mathbf{N}$ & $\mathbf{X}$ & S.D. & Median & Min & Max & Result \\
\hline \multirow{2}{*}{ Applicability } & Undergraduate & 346 & 28.17 & 9.51 & 30,00 & 10.00 & 50.00 & \multirow{2}{*}{$\mathrm{P}=0,265$} \\
& Master Degree & 34 & 30.47 & 6.71 & 31,00 & 19.00 & 41.00 & \\
\hline \multirow{2}{*}{ Impact } & Undergraduate & 346 & 27.59 & 6.99 & 28,00 & 13.00 & 41.00 & \multirow{2}{*}{$\mathrm{P}=0,557$} \\
& Master Degree & 34 & 28.58 & 7.33 & 27,00 & 18.00 & 41.00 & \\
\hline \multirow{2}{*}{ Difficulties } & Undergraduate & 346 & 20.73 & 4.07 & 21,00 & 6.00 & 30.00 & \multirow{2}{*}{$\mathrm{P}=0,006^{*}$} \\
& Master Degree & 34 & 22.64 & 3.48 & 23,00 & 15.00 & 27.00 & \\
\hline \multirow{2}{*}{ Forcing } & Undergraduate & 346 & 10.48 & 3.34 & 11,00 & 3.00 & 15.00 & \multirow{2}{*}{$\mathrm{P}=0,967$} \\
& Master Degree & 34 & 10.41 & 3.65 & 12,00 & 4.00 & 15.00 & \\
\hline \multirow{2}{*}{ Competence } & Undergraduate & 346 & 14.54 & 4.20 & 16,00 & 4.00 & 20.00 & \multirow{2}{*}{$\mathrm{P}=0,720$} \\
& Master Degree & 34 & 14.64 & 3.69 & 15,00 & 7.00 & 20.00 & \\
\hline \multirow{2}{*}{ Support } & Undergraduate & 346 & 13.34 & 2.80 & 14,00 & 4.00 & 19.00 & \multirow{2}{*}{$\mathrm{P}=0,002^{*}$} \\
& Master Degree & 34 & 11.52 & 3.24 & 12,00 & 4.00 & 16.00 & \\
\multirow{2}{*}{ Total } & Undergraduate & 346 & 148.24 & 21.37 & 150,00 & 79.00 & 214.00 & $\mathrm{P}=0,396$ \\
& Master Degree & 34 & 152.23 & 15.77 & 151,00 & 126.00 & 187.00 & \\
\hline
\end{tabular}

${ }^{*} \mathrm{p}<0.05$ significant

The difference between the scores of the "difficulty and support" subscales was found to be significant ( $\mathrm{p}<0.05)$, while the difference between the other subscales was not significant $(p>0.05)$ according to the educational status of the teachers. When the scores are compared with each other; The difference in "difficulty" sub-dimension was seen to be favored by teachers who graduated from a master's degree. In the "Support" sub-dimension, it was seen that the difference was favored by the teachers with undergraduate degrees. 
Table 7. Comparison of teachers' total and subscale averages by graduation department variable

\begin{tabular}{|c|c|c|c|c|c|c|c|c|}
\hline Sub-Scales & Department & $\mathbf{N}$ & $\mathbf{X}$ & S.D. & Median & Min & Max & Result \\
\hline \multirow{2}{*}{ Applicability } & Teaching & 366 & 28.18 & 9.30 & 29,50 & 10.00 & 50.00 & \multirow{2}{*}{$\mathrm{P}=0,019^{*}$} \\
\hline & Other & 14 & 33.57 & 8.28 & 36,00 & 17.00 & 42.00 & \\
\hline \multirow{2}{*}{ Impact } & Teaching & 366 & 27.60 & 7.01 & 28,00 & 13.00 & 41.00 & \multirow{2}{*}{$\mathrm{P}=0,214$} \\
\hline & Other & 14 & 29.71 & 7.09 & 33,00 & 20.00 & 37.00 & \\
\hline \multirow{2}{*}{ Difficulties } & Teaching & 366 & 21.01 & 3.86 & 21,00 & 7.00 & 30.00 & \multirow{2}{*}{$\mathrm{P}=0,280$} \\
\hline & Other & 14 & 18.14 & 7.19 & 20,00 & 6.00 & 26.00 & \\
\hline \multirow{2}{*}{ Forcing } & Teaching & 366 & 10.51 & 3.36 & 11,00 & 3.00 & 15.00 & \multirow{2}{*}{$\mathrm{P}=0,213$} \\
\hline & Other & 14 & 9.42 & 3.58 & 9,00 & 5.00 & 15.00 & \\
\hline \multirow{2}{*}{ Competence } & Teaching & 366 & 14.59 & 4.12 & 16,00 & 4.00 & 20.00 & \multirow{2}{*}{$\mathrm{P}=0,435$} \\
\hline & Other & 14 & 13.57 & 5.04 & 14,00 & 4.00 & 19.00 & \\
\hline \multirow{2}{*}{ Support } & Teaching & 366 & 13.23 & 2.88 & 14,00 & 4.00 & 19.00 & \multirow{2}{*}{$\mathrm{P}=0,063$} \\
\hline & Other & 14 & 11.85 & 2.56 & 12,00 & 8.00 & 16.00 & \\
\hline \multirow{2}{*}{ Total } & Teaching & 366 & 148.68 & 20.53 & 150,00 & 94.00 & 214.00 & \multirow{2}{*}{$\mathrm{P}=0,463$} \\
\hline & Other & 14 & 146.57 & 30.82 & 158,00 & 79.00 & 169.00 & \\
\hline
\end{tabular}

$* \mathrm{p}<0.05$ significant

While the difference between the "Applicability" subscale scores of the teachers was significant $(p<0.05)$, the difference between the other subscales was not significant ( $>0.05)$ when the mean scores of the teachers compared according to the graduation department variable. It was seen that the difference in "Applicability" sub-scale was in favor of teachers who graduated from other departments.

\section{Discussion}

In this study, the opinions of physical education and sports teachers about physical activity report card applications were examined. The subscale and total scores of the teachers were compared according to the gender variable, and statistically significant differences were not found between them. No national studies have been conducted on teachers' physical activity report card applicaitons in the literature. However, Farias et al. (2016) have reported gender differences in the survey conducted to determine the level of Physical Activity of children and adolescents between 2005 and 2015 in Chile (3). In addition with this, in the study by the "University of Southern Denmark Research and Innovation Centre for Human Movement and Learning", reported that 70\% of children aged 11-15 years and 13-18 years were affected by physical activity (at the specified level) and there were gender differences (18). Again, it has been reported that, female students were less likely than male counterparts to participate in vigorous physical activity at recommended levels (5). Results showed an increase in knowledge and in frequency of vigorous physical activity, which persisted to the 12-year follow-up for boys but not for girls (15). TAAG, a national multisite randomized intervention study, is currently under way at 6 sites across the country. It is testing a school and community multicomponent intervention designed to prevent the decline in physical activity in middle school girls (14). Other studies that addressed physical activity through multiple component interventions include the Australia School Project and Slice of Life which was part of a larger community study, had multiple intervention components and addressed multiple cardiovascular health behaviors and resulted smaller declines in physical activity for intervention students, with the most significant effect on girls $(6,8,12)$.

When the sub-dimension and total scores of the physical education and sports teachers are compared from the scale according to the school type, statistically significant differences were found between them. While the difference between the "Forcing, Competence, Support" sub-dimensions and the total scores is significant, the difference between the other sub-dimension scores is insignificant. The high total scores of physical education and sport teachers that working at the secondary schools may be due to the physical activity report card applications done as pilot applications in primary schools. No national or international research has been found to support research in the field.

When sub-dimension and total scores obtained from the scale according to the variable of seniority of physical education and sport teachers participating in the research are compared; Significant differences were found in the sub-dimensions of "Applicability, Forcing, Competence and Support", but no significant differences were found between the other sub-dimensions and total scores. In the "Applicability" sub-dimension, differences between 6-10 years and 11-15 years, 11-15 years and 21 years and above were found significant, while differences between the other years were not significant. While the difference between 1-5 years and 11-15 years, between 1-5 years and 16-20 years is significant in the "Forcing" sub-dimension, the difference between the other years is not significant. In the "Competence" sub-dimension, the difference between 1-5 years and 11-15 years, between 6-10 years and 11-15 years, between 11-15 years and 21 years and above were found significant, while the difference between the other years was not significant. In the "Support" sub-dimension, the difference between 1-5 years and 11-15 years, between 6-10 years and 11-15 years, between 11-15 years and 21 years and above were found significant, while the difference between the 
other years was not significant. When comparing the total scores of physical education and sport teachers according to the seniority year, the difference was not significant. It can be stated in this research that physical education and sports teachers, who have 6-10 years of professional seniority, are more likely to apply physical activity report cards. In the literature, there were no studies evaluating physical activity report card applications according to age of seniority of physical education and sports teachers. In the study, it was found that the differences between the scores of the teachers in the "Difficulty, Forcing, Competence and Support" subs-dimensions were significant, while the differences in the other sub-dimensions were not significant. When the sub-dimension scores are compared with each other; While the difference between city and town in the "difficulty" sub-dimension is significant, the difference between the other settlement regions is not significant. When the "Forcing" sub-dimension scores are compared with each other; There were significant differences between city and town, between city and village and between town and village. When the "Competence" sub-dimension scores are compared with each other; while the difference between city and town is significant, the difference among others is not significant. In the sub-dimension of "Support", the difference between the city and the town, between the city and the village is significant, while the difference between the other settlement regions is not significant. Significant differences were found working in the central province physical education and sports teachers' favor. In the literature, there were no studies evaluating the physical activity report card applications of physical education and sport teachers according to the residence location.

By the comparison of scale sub-dimension and total scores according to the educational status variable of physical education and sports teachers in the research; While the difference in the "difficulty" sub-dimension was found to be in favor of the master degree teachers, the difference in the "Support" sub-dimension was found to be in favor of the undergraduate teachers. Again, no studies have been found in the literature to support research.

\section{Result and Recommendations}

As a result of this study, physical education and sport teachers' physical activity report card applications were evaluated according to some variables; Although physical education and sport teachers participate in Physical Activity Report Card Applications measurement training, it can be said that, they do not see themselves adequately in this field as a result. It can also be expressed that Physical education and sports teachers who want to improve themselves in terms of Physical Activity Report Card Applications have not enough tools for these.

- This study can be repeated with the widespread use of Physical Activity Report Card Applications.

- The results of the research can be compared with the research that will be done later.

- The research can be applied to a larger sample group.

- Universities that are training Physical Education and Sports Teachers can add Physical Activity Report Card Applications to their curriculum as a course.

- Collaborate with schools and universities to measure physical activity together.

- Sport Sciences Faculties and Sport High Schools can evaluate the measurement results scientifically by providing material support to schools for Physical Activity Report Card measurements.

\section{Acknowledgements}

This research was presented at the $9^{\text {th }}$ International Congress on Physical Education and Sport Teachers held in Antalya on 19-22 October 2017.

\section{References}

Büyüköztürk, Ş., Kılıç, Ç. E., Akgün, Ö. E., Karadeniz, Ş., \& Demirel, F. (2012). Scientific Research Methods. Ankara: Pegem Publishing.

Centers for Disease Control and Prevention. (1997). Guidelines for school and community programs to promote lifelong physical activity among young people. MMWR Recomm Rep., 46, 1-36.

Farias, N. A.,et al. (2016). Results From Chile's 2016 Report Card on Physical Activity for Children and Youth. Journal of Physical Activity and Health; 13(2), 117-123. https://doi.org/10.1123/jpah.2016-0314

Grunbaum, J. A., Kann, L., Kinchen, S., Ross, J., Hawkins, J., Lowry, R., ... Dollins, J. (2004). Centers for Disease Control and Prevention. Youth Risk Behavior Surveillance-United States. MMWR Surveill Summ; 53, 1-96.

Hayman, L. L., Williams, C. L., Daniels, S. R., Steinberger, J., Paridon, S., Dennison, B. A., \& McCrindle, B. W. (2004). Committee on Atherosclerosis, Hypertension, and Obesity in Youth (AHOY) of the Council on Cardiovascular Disease in the Young, American Heart Association. Cardiovascular health promotion in the schools: a statement for health and education professionals and child health advocates from the Committee on Atherosclerosis, Hypertension, and Obesity in Youth (AHOY) of the Council on Cardiovascular Disease in the Young, American 
Heart Association. Circulation, 110:2266-2275. https://doi.org/10.1161/01.CIR.0000141117.85384.64

Homel, P. J., Daniels, P., Reid, T. R., \& Lawson, J. S. (1981). Results of an experimental school-based health development programme in Australia. Int. J. Health Educ., 24, 263-270.

Kahn, E. B., Ramsey, L. T., Brownson, R. C., Heath, G. W., Howze, E. H., Powell, K. E., ... Corso, P. (2002). The effectiveness of interventions to increase physical activity: a systematic review. Am J Prev Med; 22(4), 73-107. https://doi.org/10.1016/S0749-3797(02)00434-8

Kelder, S. H., Perry, C. L., \& Klepp, K. I. (1993). Community-wide youth exercise promotion: long-term outcomes of the Minnesota Heart Health Program and the Class of 1989 Study. J. Sch. Health, 63, 218 -223. https://doi.org/10.1111/j.1746-1561.1993.tb06125.x

MEB

School

Health -http://okulsagligi.meb.gov.tr/www/beden-egitimi-ve-spor-dersi-ogretmenlerine-verilecek-quotfiziksel-aktivite-uyg unluk-karnesiquot egitimi/ provided from the adress.

Özgül, F., Kangalgil, M., Çalı, O., \& Yıldız, R. (2018). Assessment scale of physical activity report card applications . Journal of Physical Education and Sports Studies, 10(1), 1-9. https://doi.org/10.30655/besad.2018.1

Pate, R. R., Davis, M. G., Robinson, T. N., Stone, E. J., McKenzie, T. L., \& Young, J. C. (2006). Promoting physical activity in children and youth: a leadership role for schools: a scientific statement from the American Heart Association Council on Nutrition, Physical Activity, and Metabolism (Physical Activity Committee) in collaboration with the Councils on Cardiovascular Disease in the Young and Cardiovascular Nursing, 114, 1214-1224. https://doi.org/10.1161/CIRCULATIONAHA.106.177052

Perry, C. L., Klepp, K., Halper, A., \& Dudovitz, B. (1987). Promoting healthy eating and physical activity patterns among adolescents: a pilot study of Slice of Life. Health Educ. Res., 2, 93-103. https://doi.org/10.1093/her/2.2.93

Seabra, A., Mendoça, D., Maia, J., Welk, G., Brustad, R., Fonseca, A., \& Seabra, A. (2013). Gender, weight status and socioeconomic differences in psychosocial correlates of physical activity in schoolchildren. Journal of Science and Medicine in Sport, 320-326. https://doi.org/10.1016/j.jsams.2012.07.008

Stevens, J., Murray, D. M., Catellier, D. J., Hannan, P. J., Lytle, L. A., Elder, J. P., ... Webber, L. S. (2005). Design of the Trial of Activity for Adolescent Girls (TAAG). Contemp Clin Trials, 26, 223-233. https://doi.org/10.1016/j.cct.2004.12.011

Tell, G. S., \& Vellar, O. D. (1988). Physical fitness, physical activity, and cardiovascular disease risk factors in adolescents: the Oslo Youth Study. Prev. Med., 17, 12-24. https://doi.org/10.1016/0091-7435(88)90068-0

THSK (2014). Turkey Physical Activity Guide. Ankara: Ministry of Health.

THSK (2017). Turkey Physical Activity Guide. Ankara: Ministry of Health. http://ailehekimligi.gov.tr/salk-ve-bakm/265-fiziksel-aktivite.html provided from the adress.

University of Southern Denmark Research and Innovation Centre for Human Movement and Learning. (2016). The Danish Physical Activity Report Card for Children and Youth.

Yüzgül, A., \& Müniroğlu, S. (2001). Investigation of Physical Characteristics of Children in 7-12 Age Group in a Private School in Ankara. 3rd International Mediterranean Sports Sciences Congress, pp. 343-356. Antalya.

\section{Copyrights}

Copyright for this article is retained by the author(s), with first publication rights granted to the journal.

This is an open-access article distributed under the terms and conditions of the Creative Commons Attribution license which permits unrestricted use, distribution, and reproduction in any medium, provided the original work is properly cited. 